\title{
The polymerase L528M mutation cooperates with nudeotide binding-site mutations, increasing hepatitis B virus replication and drug resistance
}

\author{
Suzane Kioko O no, ${ }^{1,2}$ Naoya Kato, ${ }^{1}$ Yasushi Shiratori, ${ }^{1}$ Jun Kato, ${ }^{1}$ Tadashi Goto, ${ }^{1}$ \\ Raymond F. Schinazi, ${ }^{3}$ Flair JoséCarrilho, ${ }^{2}$ and M asao O mata ${ }^{1}$ \\ 1D epartment of Gastroenterology, Faculty of M edicine, University of Tokyo, Tokyo, Japan \\ ${ }^{2}$ D epartment of Gastroenterology, School of M edicine, University of Sao Paulo, Sao Paulo, Brazil \\ ${ }^{3}$ Veterans Affairs M edical Center and D epartment of Pediatrics, Emory University School of M edicine, Atlanta, Georgia, USA \\ Address correspondence to: N aoya Kato, D epartment of Gastroenterology, Faculty of M edicine, \\ University of Tokyo, 7-3-1 Hongo, Bunkyo-ku, Tokyo 113-8655, Japan. \\ Phone: 81-3-3815-5411 ext. 33056; Fax: 81-3-3814-0021; E-mail: kato-2im@h.u-tokyo.ac.jp.
}

Received for publication August 17, 2000, and accepted in revised form January 15, 2001.

\begin{abstract}
After receiving lamivudine for 3 years to treat chronic hepatitis B, $67-75 \%$ of patients devel op B-domain L528M , C-domain M 552I, or M 552V mutations in the HBV polymerase that render hepatitis $B$ virus (HBV) drug-resistant. The aim of this study was to evaluate the influence of these mutations on viral replication and resistance to antiviral agents. We investigated the replication fitness and susceptibility of the wild-type and five mutant HBVs (L528M, M 552I, M 552V, L528M / M 552I, and L528M / M 552V) to 11 compounds [lamivudine, adefovir, entecavir (BM S200475) (+)-BCH-189 ( \pm )-FTC (racivir) (-)-FTC (emtricitabine) (+)-FTC, L-D 4FC, L-FM AU (clevudine), D-DAPD, and (-)-carbovir] by transfecting HBV DNA into hepatoma cells and monitoring viral products by Southern blotting. The replication competency of thesingle C-domain mutants M 552 and M 552V was markedly decreased compared with that of wild-type HBV. However, addition of the B-domain mutation L528M restored replication competence. Only adefovir and entecavir were effective against all five HBV mutants, and higher doses of these compounds were necessary to inhibit the double mutants compared with the single mutants. The B-domain mutation (L528M) of HBV polymerase not only restores the replication competence of C-domain mutants, but also increases resistance to nucleoside anal ogues.
\end{abstract}

J. Clin. Invest. 107:449-455 (2001).

\section{Introduction}

Despite the availability for al most 20 years of safe and effective vaccines against hepatitis $B$, chronic infection with hepatitis $B$ virus (HBV) remains among the ten most common causes of death worldwide (1). RecentIy, lamivudine [(-)- $\beta$-L-2', $3^{\prime}$-dideoxy-3'-thiacytidine (3TC)] became the first approved oral therapy for the treatment of HBV (2). Clinical data have shown that lamivudine treatment rapidly reduces the levels of HBV D NA, is well tolerated, and improves liver histology $(3,4)$. H owever, a defined course of 52 weeks' treatment provides a sustained response rate of $17-33 \%$ (loss of $\mathrm{HBeAg}$ ). Discontinuation of therapy at 52 weeks is followed by relapse in patients who do not lose HBeAg by that point, and these patients may benef it from long-term therapy $(5,6)$. H owever, prolonged use of lamivudine therapy has been associated with increased emergence of lamivudineresistant HBV with amino-acid substitutions in the B domain (L528M) and in the YMDD motif of the C domain (M 552I and M 552V) of the viral DNA polymerase (7-14). The emergence rate of lamivudine-resistant $\mathrm{HBV}$ ranges from $17-46 \%$ at 1 year to as high as $67-75 \%$ after 3-4 years of continuous therapy $(4,6,15)$.
The YMDD motif, a conserved motif in RNAdependent DNA polymerase, is involved in nucleotide binding in the catalytic site of the polymerase $(16,17)$. It was previously demonstrated that owing to replication competence and lamivudine sensitivity, viruses having M 552I or M 552V sequences may appear during treatment with lamivudine $(18,19)$. On theother hand, the $B$ domain of DNA polymerase is an element responsible for template positioning (20). Amino acid substitution in the B domain (L528M) of HBV polymerasewas described in patients receiving lamivudine, accompanying the M 552I or M $552 \mathrm{~V}$ mutation, and in patients recei ving famciclovir without any mutation in the YMDD motif $(10,21)$.

Liaw et al. recently reported that exacerbation occurred in $41 \%$ of patients after the emergence of YMDD motif mutations during continued use of lamivudine (22). In addition, lamivudine-resistant $\mathrm{HBV}$ is associated with advanced hepatic fibrosis and severe microinflammatory changes in patients with recurrent HBV infection after orthotopic liver transplantation (23). Lamivudine-resistant HBV also can cause severe hepatitis in patients coinfected with HIV and HBV (24). Thus, theneed to develop new antivirals 
and new strategies to treat $\mathrm{HBV}$ infections is becoming clear. Previously, we demonstrated that ad efovir decreased replication of wild-type and lamivudineresistant H BV (25); however, new antiviral s are becoming available, and there is a pressing need for further studies to determine their potential as single agents and for combination chemotherapy.

The aim of this study was to evaluate the replication competence and susceptibility of wild-type HBV and five different mutants (L528M, M 552I, M 552V, L528M/M 552I, and L528M/M 552V) to 11 drugs [lamivudine; 9-(2-bis [pivaloyloxymethyl] methoxyethyl) adenine (adefovir); [1S-(1 $\alpha, 3 \alpha, 4 \beta)$ ]-2-amino-1,9-dihydro-9[4-hydroxy-3-(hydroxymethyl)-2-methylenecyclopentyl]-6H -purin-6-one (entecavir); (+)- $\beta-2^{\prime}, 3^{\prime}-$ dideoxy-3'-thiacytidine (BCH-189) (theplus enantiomer of lamivudine); ( \pm - $\beta$ - $2^{\prime}, 3^{\prime}$-dideoxy-5-fluoro-3'-thiacytidine (FTC) (racivir); (-)-FTC (emtricitabine, coviracil); $(+)-F T C$ (the plus enantiomer of emtricitabine); (-)- $\beta$ $L-2^{\prime}, 3^{\prime}$-dideoxy-2', $3^{\prime}$-didehydro-5-fluorocytidine (L-D 4FC); 2'-fluoro-5-methyl- $\beta$-L-arabinofuranosyluracil (L-FM AU, clevudine); (-)- $\beta$-D-2,6-diaminopurine dioxolane (DAPD); and (-)-carbovir].

\section{Methods}

Chemicals. Lamivudinewas generously donated by GlaxoWellcome(M iddlesex, United Kingdom). Adefovir was a gift from Gilead Sciences (Foster City, California, USA). Entecavir (BMS-200475), a guanosineanalogue, was synthesized by the method of Bisacchi et al . (26). The other antiviral agents weresynthesized in R.F. Schinazi's laboratory. All compounds were coded and remained coded until the preliminary results were obtained.

Cells. HuH-7 cells (Human Science Research Resource Bank, O saka, Japan) (27) were cultured in DMEM (Life Technologies Inc., Rockville, M aryland, USA) supplemented with $10 \%$ FBS. The 2.2 .15 cells (clonal cells derived from $\mathrm{H}$ epG2 cells that weretransfected with a plasmid containing HBV DNA) that secrete HBV virions were kindly provided by G. Acs (M ount Sinai M edical Center, N ew York, N ew York, USA) (28). The 2.2.15 cells weremaintained in DM EM supplemented with $20 \% \mathrm{FBS}$.

HBV plasmids(wild-type, "single" and "double" mutants, and dimer). Wild-typeH BV DNA, extracted from theserum of

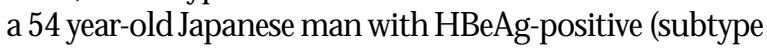
ayw, genotype D) cirrhosis, was amplified and cloned as described previously $(18,25)$. HBV D N A was extracted from $100 \mu$ l serum using a SepaG enekit (Sanko Junyaku, Tokyo, Japan) according to the manufacturer's instructions. Five mutants were prepared. First, three single mutants (L528M , M 552I, and M 552V) weremadeby substituting nucleotides in order to change the codon for Met in theYMDD motif to lle (M 552I) or Val (M 552V) or a codon for Leu in theB domain to M et (L528M) using a Quickchangesite-directed mutagenesis kit (Stratagene, LaJolla, California, USA). Similarly, two doublemutants (L528M/M 552I and L528M/M 552V) were constructed by adding $\mathrm{L} 528 \mathrm{M}$ substitution to the $\mathrm{C}$-domain single mutants M 552I and M 552V. To confirm theintroduction of mutations, the polymerase genes of the mutants were sequenced using a cycle DN A sequencing system (Perkin-Elmer Applied Biosystems, Foster City, California, USA) as described previously (29).

Plasmid pSM 2 containing a head-to-tail dimer of HBV was kindly provided by S. Günther (HeinrichPette-Institut fur Experiementelle Virologie, $\mathrm{Ham}$ burg, Germany) (30).

Transfection of HBV DNA into HuH -7 cells. HuH-7 cells at $80-90 \%$ confluence (in 60-mm dishes) were transfected with $0.9 \mu \mathrm{g}$ full-length HBV DNA wild-type, mutants, or PSM 2 using Effectenetransfection reagent (QIAGEN GmbH, Hilden, Germany) according to the manufacturer's instructions. Twenty-four hours after transfection, the medium was changed and reincubated with drug-free medium or medium containing $0.0001,0.001,0.01,0.1,1$, or $10 \mu \mathrm{M}$ of each compound. M edium and cells (rinsed three times with cold PBS) were harvested 3 days later. The efficiency of transfection was monitored by cotransfecting $0.1 \mu \mathrm{g} \beta$-galactosidase expression plasmid, pCM V $\beta$ (CLONTECH Laboratories Inc., California, USA). Assays for $\beta$-galactosidase in extracts of $\mathrm{HuH}-7$ cells were performed as described previously (25).

Themedium of 2.2 .15 cells at $80-90 \%$ confluence (in 60-mm dishes) was changed and reincubated with drug-free medium or medium containing 0.0001 , $0.001,0.01,0.1,1$, or $10 \mu \mathrm{M}$ of lamivudine or entecavir. M edium and cells (rinsed three times with cold PBS) were harvested 3 days later.

Experiments were performed at least in duplicate.

I solation of coreparticle-related H BV DNA. Purification of HBV DNA from intracellular core particles was accomplished using the method described by Günther et al. (30) with minor modifications. Briefly, cells were suspended in $500 \mu \mathrm{l}$ of lysis buffer containing $50 \mathrm{mM}$ Tris- $\mathrm{HCl}(\mathrm{pH}$ 7.4), $1 \mathrm{mM}$ EDTA, and 1\%N P-40, transferred to an Eppendorf tube, vortexed, and allowed to stand on ice for 15 minutes. Nuclei were pelleted by centrifugation at $4^{\circ} \mathrm{C}, 15,000 \mathrm{~g}$ for 1 minute. The supernatant was transferred to a new tube, adjusted to $10 \mathrm{mM} \mathrm{M} \mathrm{gCl}$, and digested with $100 \mu \mathrm{g} / \mathrm{ml}$ of DN ase I for 30 minutes at $37^{\circ} \mathrm{C}$. To stop the reaction, EDTA was added to a final concentration of $25 \mathrm{mM}$. Then, $0.5 \mathrm{mg} / \mathrm{ml}$ proteinase $\mathrm{K}$ and $1 \%$ sodium dodecylsulfate were added and incubated at $50^{\circ} \mathrm{C}$ for 4 hours. Phenol-chloroform (1:1) extraction was performed, and then the nucleic acids were ethanol precipitated along with a glycogen carrier.

Southern blot hybridization of HBV DNA. HBV DNA was resolved in $1.5 \%$ agarosegels, transferred to nylon membranes (H ybond $\mathrm{N}+$, Amersham Pharmacia Biotech, Little Chalfont, United Kingdom) by Southern blotting, and hybridized with an alkalinephosphatase-labeled wild-type full-length HBV DN A probegenerated with the Gene I mages AlkPhos Direct labeling system (Amersham Pharmacia Biotech). Chemiluminescent detection was performed with CD P-Star (Amersham Pharmacia 
Biotech) and analyzed using an LAS1000 image analyzer (Fuji Photo Film, Tokyo, Japan).

Drug susceptibility analysis (determination of $\mathrm{EC}_{50}$ ) by measuring singlestranded HBV DNA. To compare the effect of the 11 antiviral agents on the wild-type HBV and five mutants, $\mathrm{HuH}-7$ cells were transfected with HBV D NA, and the antivirals were added at a concentration of $10 \mu \mathrm{M}$. For those antivirals that inhibited the replication of $\mathrm{HBV}$ by more than $50 \%$ at this concentration, increasing concentrations $(0.0001$ to 10 $\mu \mathrm{M}$ ) of the compound were applied to calculate the effective concentration required to reduce $\mathrm{HBV}$ replication by $50 \%\left(\mathrm{EC}_{50}\right)$. To evaluate the susceptibility of $\mathrm{HBV}$ to the antiviral agents, Southern blot hybridization of DNA extracts from transfected cells was performed. The single-stranded HBV DN A band, previously shown to represent HBV intermediates $(30,31)$, was analyzed to assess the efficacy of the RT inhibitors on HBV replication. This single-stranded band was quantified and normalized for transfection efficiency based on $\beta$-galactosidase activity. $D$ ata are shown as themean \pm SD of at least two experiments.

\section{Results}

Replication competency of the fiveH BV mutants. To evaluate the effect of mutations in the polymerasegene on HBV replication, the replication ability of the wild-type HBV and five mutants (L528M, M552I, M552V, L528M / M 552I, and L528M / M 552V) was examined in a transient transfection cell culture assay system. Southern blot hybridization of DNA extracts showed thepresence of a single-stranded band (representative of HBV replication intermediates) for each construct, indicating that they were replication-competent (Figure 1). These bands were quantified, adjusted for the efficiency of transfection according to the $\beta$-galactosidase assay of cotransfected $p C M V \beta$, and determined by taking the singlestranded band of thewild typeas 100\% Although the single B-domain mutation L528M did not affect replication ability, the single $\mathrm{C}$-domain mutations M 552I and M 552V had markedly decreased replication ability compared with the wild-type(14\%and $10 \%$ of the wild-typeH BV, respectively) (Figure 1). In contrast, the double mutants L528M/M 552I and L528M/M 552V had better replication ability (55\% and $68 \%$ of the wildtype HBV, respectively) when compared with thesingle C-domain mutants M552I and M552V, the double mutant replicating 3.9 times more than the M 552I mutant and 6.8 times more than the M $552 \mathrm{~V}$ mutant.

Effect of antiviral agents against wild-type H BV. First, to assess the effect of the 11 compounds on wild-typeH BV replication in vitro, $\mathrm{HuH}-7$ cells transfected with wildtypeHBV DN A wereincubated with $10 \mu \mathrm{M}$ of each compound. Southern blot hybridization of DNA extracts showed the presence of a singlestranded band in the drug-free samples. All compounds except (+)-BCH-189 decreased the singlestranded band of wild-type HBV, showing that wild-typeHBV is susceptibleto the majority of the compounds tested (Table1). Seven compounds [lamivudine, adefovir, entecavir ( \pm )-FTC (-)-FTC, L-D 4FC, and L-FM AU] inhibited thereplication of wildtype HBV morethan $50 \%$ at a concentration of $10 \mu \mathrm{M}$. Therefore, the $\mathrm{EC}_{50}$ of theseseven drugs was determined against wild-type $\mathrm{HBV}$ using increasing concentrations $(0.0001,0.001,0.01,0.1,1$, and $10 \mu \mathrm{M})$ by performing at least two independent experiments (Figure 2 and Table 1). Entecavir, L-D4FC, L-FM AU (-)-FTC, lamivudine, adefovir, and ( \pm )-FTC (in relative order of potency) were "effective" ( $\left.E C_{50}<10 \mu \mathrm{M}\right)$ against wild-typeH BV with an $E_{50}$ of $0.00036,0.033,0.053,0.24,0.56,0.58$, and 1.85 $\mu \mathrm{M}$, respectively (Tables 1 and 2). Entecavir, L-D 4FC, L-FM AU, and (-)-FTC inhibited wild-type HBV replication $1,556,17,11$, and two times more efficiently than did lamivudine, respectively.

Comparison of the effect of lamivudine and entecavir against wild-typeH BV in pSM 2-tran ffected H uH 7 cellsand 2.2.15 cells. The potency of lamivudine and entecavir against wildtype HBV was al so validated in pSM 2-transfected $\mathrm{HuH} 7$ cells and 2.2.15 cells. The $\mathrm{EC}_{50}$ values of lamivudineand entecavir were 0.19 and $0.0008 \mu \mathrm{M}$, respectively, in pSM 2-transfected HuH 7 cells; and 0.55 and 0.00025 $\mu \mathrm{M}$, respectively, in 2.2.15 cells (Figure 3). Entecavir inhibited wild-type HBV replication 2,200 times more strongly than did lamivudine in pSM2-transfected $\mathrm{HuH} 7$ cells, and 237 times morestrongly in 2.2 .15 cells.

Effect of antiviral agents on three single mutant H BVs. To analyzethein vitro antiviral effect of thecompounds on threesingle mutant $\mathrm{HBVs}, \mathrm{HuH}-7$ cells transfected with L528M , M 552I, or M 552V were incubated with $10 \mu \mathrm{M}$ of each compound. Adefovir, entecavir ( \pm -FTC (-)-FTC, L-D 4FC, and L-FM AU inhibited replication of all three

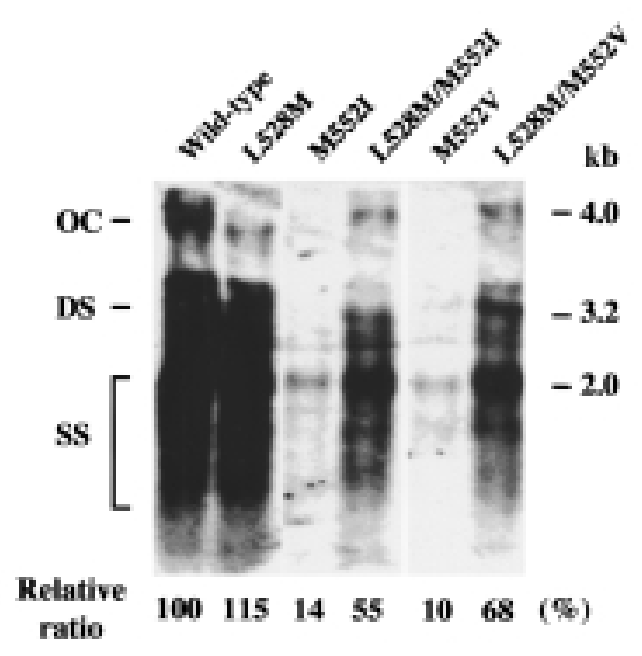

Figure 1

Southern blot hybridization analysis of replication of wild-type HBV and five mutants. Lanes correspond to DNA extracted from viral core particles derived from $\mathrm{HuH}-7$ cells that were transfected with DNA of wild-type HBV or one of five mutants. Single-stranded bands (SS) were quantified using an LAS1000 image analyzer and then normalized for transfection efficiency based on $\beta$-galactosidase activity. The relative ratio of the normalized single-stranded band is shown below each lane, assuming the single-stranded band of wild-type HBV to be $100 \%$. OC, open circular; DS, double-stranded HBV DNA. 
Figure 2

Representative Southern blot hybridization used to determine the $\mathrm{EC}_{50}$ value of entecavir against wild-type HBV. (a) Southern blot hybridization analysis of replication of the wild-type treated with entecavir. Lanes correspond to DNA extracted from viral core particles derived from $\mathrm{HuH}-7$ cells that were transfected with wild-type HBV DNA and incubated with increasing concentrations $(00001,0.001,0.01$, and $0.1 \mu \mathrm{M})$ of entecavir. OC, open circular; DS, doublestranded; SS, single-stranded HBV DNA. (b) Diagram of replication of wild-type HBV treated with entecavir. Single-stranded bands (SS) were quantified using an LAS1000 image analyzer and then normalized for transfection efficiency based on $\beta$ galactosidase activity. The single-stranded band of the wild-type without entecavir was calculated as 100 . $\mathrm{EC}_{50}$ was determined to be $0.00036 \mu \mathrm{M}$.
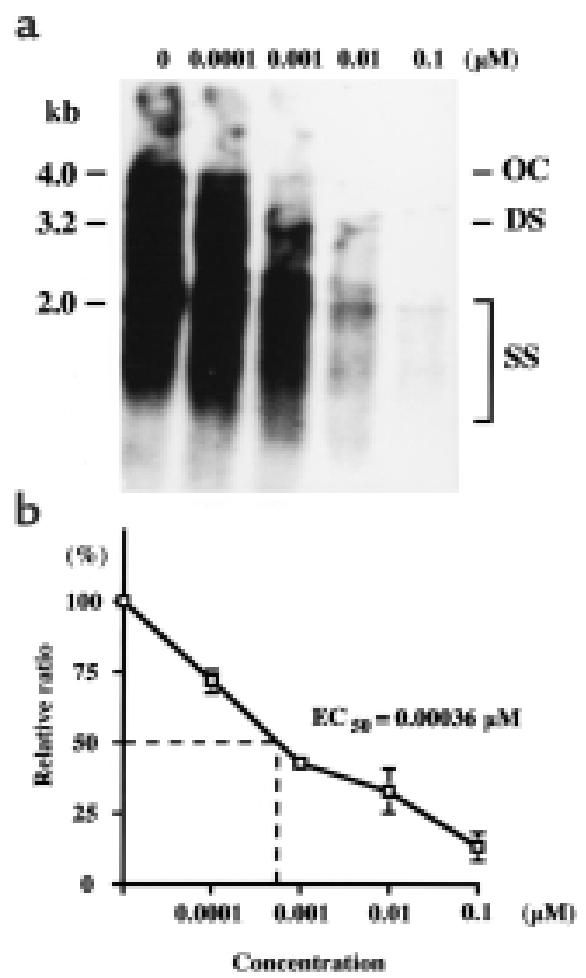

Effect of antiviral agents against two double mutants $\mathrm{HBV}$. To analyzethein vitro antiviral effect of the previously mentioned 11 compounds on two doubleHBV mutants, $\mathrm{HuH}-7$ cells transfected with L528M/M552I or L528M / M 552V were incubated with $10 \mu \mathrm{M}$ of each compound. Only adefovir and entecavir inhibited replication of these two double mutant HBVs more than $50 \%$ at a concentration of $10 \mu \mathrm{M}$ (Table1). The $\mathrm{EC}_{50}$ values of ad efovir and entecavir against the two double mutant HBVs were determined using increasing concentrations of the compounds $(0.0001$ to $10 \mu \mathrm{M})$, by performing at least two independent experiments (Tables 1 and 2). The $E C_{50}$ values of adefovir for the mutants were four to 16 times higher than those for wild-type $\mathrm{HBV}$ and the $\mathrm{EC}_{50}$ values of entecavir for the

single mutant $\mathrm{HBV}$ s morethan $50 \%$ at a concentration of $10 \mu \mathrm{M}$ (Table 1). Therefore, we determined the EC $C_{50}$ of thesesix drugs against thethreesinglemutants using increasing concentrations $(0.0001-10 \mu \mathrm{M})$ of the compounds by performing at least two independent experiments (Table 1). ( \pm )-FTC and (-)-FTC were effective only against singleB-domain mutant L528M , whereas L-D 4FC and L-FM AU wereeffective against both single B-domain mutant L528M and C-domain mutant M 552V (Tables 1 and 2). However, only adefovir and entecavir were effectiveagainst all threesinglemutants: L528M , M 552I, and M 552V (Tables 1 and 2). Although adefovir and entecavir were effective against all three singlemutants, the $\mathrm{EC}_{50}$ values of adefovir and entecavir for the three single mutants were up to 8.6 and 166 times higher than for wild-type HBV, respectively. mutants were 694 to 778 times higher than those for wild-typeH BV. Although thesingleC-domain mutants M 552I and M 552V were less susceptible to entecavir than werewild-type $\mathrm{BV}$, theaddition of the B-domain L528M mutation to the $C$-domain mutants (double mutants L528M/M 552I and L528M / M 552V) resulted in HBV that was more resistant to entecavir.

\section{D iscussion}

Although lamivudine was approved for the treatment of patients with chronic hepatitis $B$, short-term treatment is usually insufficient to clear thevirus. Moreover, long-term treatment is associated with the development of drug-resistant HBV in $14-75 \%$ of patients (2, $4,15,32)$. These lamivudine-resistant HBV harbor M 552I or M 552V mutations in the C domain of the

Table 1

$\mathrm{EC}_{50}$ values of compounds and level of replication of wild-type and five mutants $\mathrm{HBV}$ at $10 \mu \mathrm{M}$ concentration treatment

\begin{tabular}{|c|c|c|c|c|c|c|c|c|c|c|c|c|}
\hline \multirow[b]{2}{*}{ Compound } & \multicolumn{2}{|c|}{ Wild } & \multicolumn{2}{|c|}{ L528M } & \multicolumn{2}{|c|}{ M 552I } & \multicolumn{2}{|c|}{ M 552V } & \multicolumn{2}{|c|}{ L528M/M 552I } & \multicolumn{2}{|c|}{ L528M / M 552V } \\
\hline & $10 \mu \mathrm{MA}^{\mathrm{A}}$ & $\mathrm{EC}_{50}$ & $10 \mu M^{A}$ & $\mathrm{EC}_{50}$ & $10 \mu \mathrm{MA}^{\mathrm{A}}$ & $\mathrm{EC}_{50}$ & $10 \mu \mathrm{M}^{\mathrm{A}}$ & $\mathrm{EC}_{50}$ & $10 \mu \mathrm{M}^{\mathrm{A}}$ & $\mathrm{EC}_{50}$ & $10 \mu \mathrm{MA}^{\mathrm{A}}$ & $\mathrm{EC}_{50}$ \\
\hline $\begin{array}{l}\text { Lamivudine } \\
\text { Adefovir } \\
\text { Entecavir } \\
\text { (+)-BCH-189 } \\
\text { (+)-FTC } \\
\text { (-)-FTC } \\
\text { (+)-FTC } \\
\text {-D4FC } \\
\text {--FMAU } \\
\text { D-DAPD } \\
\text { (-)-Carbovir }\end{array}$ & $\begin{array}{c}1.3 \pm 0.2 \\
10.5 \pm 6.1 \\
3.6 \pm 0.4 \\
9103.2 \pm 22.3 \\
13.6 \pm 12.8 \\
7.1 \pm 1.0 \\
79.7 \pm 5.4 \\
1.5 \pm 0.2 \\
16.5 \pm 10.0 \\
75.9 \pm 23.6 \\
57 \pm 32.2\end{array}$ & $\begin{array}{l}0.56 \\
0.58 \\
0.0004 \\
>10 \\
1.85 \\
0.24 \\
>10 \\
0.033 \\
0.053 \\
>10 \\
>10\end{array}$ & $\begin{aligned} 59.2 & \pm 8.6 \\
8.8 & \pm 10.3 \\
12.7 & \pm 4.9 \\
142.2 & \pm 28.0 \\
39.6 & \pm 6.4 \\
31.5 & \pm 5.5 \\
111.0 & \pm 12.3 \\
4.8 & \pm 6.7 \\
39.6 & \pm 17.8 \\
99.4 & \pm 8.9 \\
74.9 & \pm 6.6\end{aligned}$ & $\begin{array}{l}>10 \\
0.45 \\
0.0005 \\
>10 \\
5.1 \\
2.7 \\
>10 \\
0.13 \\
1.2 \\
>10 \\
>10\end{array}$ & $\begin{aligned} 176.8 & \pm 17.9 \\
30.8 & \pm 20.0 \\
16.4 & \pm 3.5 \\
107.5 & \pm 15.6 \\
98.7 & \pm 20.2 \\
105.9 & \pm 32.2 \\
104.8 & \pm 4.5 \\
145.5 & \pm 31.6 \\
91.8 & \pm 13.8 \\
132 & \pm 29.9 \\
95.7 & \pm 30.3\end{aligned}$ & $\begin{array}{l}>80^{B} \\
4.5^{B} \\
0.06 \\
>10 \\
>10 \\
>10 \\
>10 \\
>10 \\
>10 \\
>10 \\
>10\end{array}$ & $\begin{aligned} 76.9 & \pm 15.8 \\
32.5 & \pm 2.9 \\
5.2 & \pm 1.0 \\
131.0 & \pm 10.9 \\
83.5 & \pm 10.6 \\
102.3 & \pm 25.1 \\
108.3 & \pm 23 \\
5.4 & \pm 6.5 \\
9.6 & \pm 15.9 \\
118.7 & \pm 29.6 \\
107.8 & \pm 19.7\end{aligned}$ & $\begin{array}{l}33^{\mathrm{B}} \\
4.9^{\mathrm{B}} \\
0.003 \\
>10 \\
>10 \\
>10 \\
>10 \\
1.8 \\
0.74 \\
>10 \\
>10\end{array}$ & $\begin{array}{c}111.7 \pm 17.3 \\
47.2 \pm 6.5 \\
42.3 \pm 5.3 \\
98.3 \pm 8.9 \\
125.1 \pm 30.8 \\
144.1 \pm 19.0 \\
96.6 \pm 12.4 \\
99.5 \pm 9.9 \\
127.3 \pm 20 \\
134.6 \pm 4.1 \\
92.4 \pm 8.7\end{array}$ & $\begin{array}{l}>10 \\
9.5 \\
0.25 \\
>10 \\
>10 \\
>10 \\
>10 \\
>10 \\
>10 \\
>10 \\
>10\end{array}$ & $\begin{array}{c}126.7 \pm 9.6 \\
23.8 \pm 13.3 \\
34.7 \pm 18.11 \\
173.8 \pm 15.4 \\
122.3 \pm 4.7 \\
87.6 \pm 12.1 \\
101.9 \pm 8.9 \\
128.3 \pm 28 \\
104 \pm 24.4 \\
105.7 \pm 9.3 \\
95.7 \pm 30.3\end{array}$ & $\begin{array}{l}>80^{\mathrm{B}} \\
2.2^{\mathrm{B}} \\
10.28 \\
>10 \\
>10 \\
>10 \\
>10 \\
>10 \\
>10 \\
>10 \\
>10\end{array}$ \\
\hline
\end{tabular}

${ }^{A} N$ umbers indicate the mean $\pm S D$ in percent of replication of wild-type and mutant HBV treated with $10 \mu \mathrm{M}$ of compounds. ${ }^{B}$ Ref. 25 . 


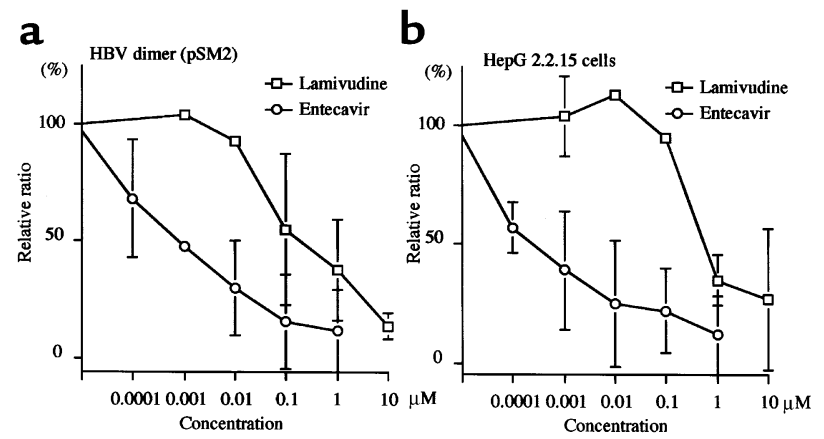

Figure 3

Susceptibility of HBV dimer (pSM 2) (a) and HBV from 2.2.15 cells (b) to lamivudine and entecavir: drug inhibition curves of wild-type $\mathrm{HBV}$ transfected into $\mathrm{HuH}-7$ cells treated with the indicated concentrations of lamivudine and entecavir.

polymerase gene. The L528M mutation frequently accompanies $\mathrm{M} 552 \mathrm{~V}$ and has recently been reported to accompany M 552I occasionally (7-10, 12). To summarize three published reports, the clinical frequency of lamivudineresistant mutants was $18.6 \%$ for M 552I, $1.4 \%$ for M 552V, 11.4\% for L528M / M 552I, and $64.3 \%$ for L528M / M 552V $(10,11,13)$.

Given that mutations in the polymerase gene have been associated with changes in the replication competency of the virus $(18,19)$, we examined the influence, singly or in combination, of theB-domain mutation (L528M) and the two C-domain mutations (M 552I and M 552V) on replication ability. Compared with the wild-type HBV, the singleC-domain mutants M 552I and M 552V had markedly decreased replication abilities (18). Of particular interest, the doublemutants with both B- and C-domain mutations (L528M / M 552I and L528M/M 552V) replicated significantly better than did the singleC-domain mutants, suggesting that the B-domain mutation L528M rescued the defective replication competence of the $\mathrm{C}$-domain mutants. It was previously indicated that L528M could compensate for the impact of a mutation in the YMDD motif on viral replication in vitro (33). The B-domain L528 in the amino acid 521-537 helix is closeenough to interact with M 552 of the YMDD loop in a hypothetical molecular model of HBV RT (10). It could be speculated that the L528M mutation reduces theimbalance of conformation caused by the M552V and M552I mutations, thereby improving the replication competence of singleC-domain mutants.

Of the 11 compounds tested, entecavir, L-D 4FC, L-FM AU (-)-FTC, lamivudine, and adefovir inhibited the replication of wildtype HBV effectively, with an $\mathrm{EC}_{50}$ less than 1 $\mu \mathrm{M}$. These results are comparablewith previous reports that demonstrated inhibition of $\mathrm{HBV}$ replication by $50 \%$ at concentrations of less than $0.1 \mu \mathrm{M}$ in 2.2 .15 cells (34-38).
Because several different groups tested these compounds in different ways, it was difficult to compare their $\mathrm{EC}_{50}$ values, as they varied according to the assay used, cell type used, marker of viral replication selected, composition of the medium, and time in culture (39). Westudied the effect of the 11 compounds simultaneously. Therefore, wecould determineand compare their relative potencies. Entecavir, L-D4FC, L-FM AU, and (-)-FTC inhibited wild-type HBV replication two to 1,556 times more than lamivudine. Similar results were obtained in 2.2.15 cells and pSM 2transfected HuH 7 cells. In these cells, entecavir was 237-2,200 times more potent than lamivudine. In general, the more potent the antiviral agents used to suppress viral replication, the less likely the virus is to develop drug-resistant mutations, because mutations arise as replication errors (40-43). Therefore, in the absence of toxicological considerations of these experimental agents, entecavir, L-D 4FC, and L-FM AU are potentially useful "first line" drugs for the treatment of HBV. However, it must be noted that in vitro sensitivities do not al ways match thesensitivities of virus infection in humans in vivo. Therefore, the ultimate test is their effectiveness in patients with chronic hepatitis $B$.

Whileadefovir, entecavir (+)-FTC (-)-FTC, L-D 4FC, and L-FM AU areeffective $\left(E_{50}<10 \mu M\right)$ against someof the five lamivudine-resistant HBV mutants, only adefovir and entecavir areeffectiveagainst all fivemutants. As previously described, adefovir might be a good treatment option in thosepatients who havefailed lamivudinetherapy because of drug-resistant HBV (25). In fact, it was recently demonstrated that adefovir resulted in a rapid and sustained reduction in HBV DNA levels associated with improvement in liver function in patients who failed to respond to lamivudinetherapy (44). In addition, based on our data, entecavir could bean option for the treatment of lamivudineresistant mutants. However, it must be noted that the $\mathrm{EC}_{50}$ values for lamivudine-resistant mutants were 2 to 778 times higher than those for the wild-typeH BV. Therefore, the dose of entecavir necessary
Table 2

Comparison of potencies of compounds against wild-type and lamivudine-resistant mutant HBV

\begin{tabular}{|c|c|c|c|c|c|c|}
\hline & Wild & L528M & M 552I & M 552V & -528M / M 552I & L528M / M 552V \\
\hline 1st & $\begin{array}{l}\text { Entecavir } \\
(0.00036)^{\mathrm{A}}\end{array}$ & $\begin{array}{c}\text { Entecavir } \\
(0.00054)\end{array}$ & $\begin{array}{c}\text { Entecavir } \\
(0.06)\end{array}$ & $\begin{array}{l}\text { Entecavir } \\
(0.0031)\end{array}$ & $\begin{array}{c}\text { Entecavir } \\
(0.25)\end{array}$ & $\begin{array}{c}\text { Entecavir } \\
(0.28)\end{array}$ \\
\hline 2nd & $\begin{array}{l}\text { L-D4FC } \\
(0.033)\end{array}$ & $\begin{array}{c}\text { L-D 4FC } \\
(0.13)\end{array}$ & $\begin{array}{c}\text { Adefovir } \\
(4.5)\end{array}$ & $\begin{array}{c}\text { L-FM AU } \\
(0.74)\end{array}$ & $\begin{array}{c}\text { Adefovir } \\
(9.5)\end{array}$ & $\begin{array}{c}\text { Adefovir } \\
(2.2)\end{array}$ \\
\hline $3 r d$ & $\begin{array}{l}\text { L-FM AU } \\
(0.053)\end{array}$ & $\begin{array}{c}\text { Adefovir } \\
(0.45)\end{array}$ & & $\begin{array}{c}\text { L-D 4FC } \\
(1.8)\end{array}$ & & \\
\hline 4th & $\begin{array}{c}(-)-\text { FTC } \\
(0.24)\end{array}$ & $\begin{array}{c}\text { L-FM AU } \\
(1.2)\end{array}$ & & $\begin{array}{c}\text { Adefovir } \\
\text { (4.9) }\end{array}$ & & \\
\hline 5th & $\begin{array}{c}\text { Lamivudine } \\
(0.56)\end{array}$ & $\begin{array}{c}(-)-\mathrm{FTC} \\
(2.7)\end{array}$ & & & & \\
\hline 6th & $\begin{array}{c}\text { Adefovir } \\
(0.58)\end{array}$ & $\begin{array}{c}( \pm)-\mathrm{FTC} \\
(5.1)\end{array}$ & & & & \\
\hline 7th & $\begin{array}{c}( \pm)-F T C \\
(1.85)\end{array}$ & & & & & \\
\hline
\end{tabular}

${ }^{A} C_{50}$ value of each compound is shown in parentheses. 
to treat lamivudineresistant mutants would beconsiderably higher than that used for wild-typeHBV.

L-D 4FC and L-FM AU were effective against singleBor C-domain mutants L528M and M 552V with an $\mathrm{EC}_{50}$ of less than $2 \mu \mathrm{M}$, but were ineffective against the double mutant L528M/M 552V, with an $\mathrm{EC}_{50}$ exceeding 10 $\mu \mathrm{M}$. In addition, the $\mathrm{EC}_{50}$ of entecavir for the double mutants was about 500 times higher than that for the single B-domain mutant L528M , and 90 times higher than that for the singleC-domain mutants. The addition of the B-domain mutation L528M to C-domain mutants may contributeto increased levels of resistance to entecavir, L-D 4FC, and L-FM AU but does not seem to increasethelevel of resistanceto adefovir, suggesting that the resistance pattern for adefovir is uniqueand different from those of entecavir, L-D 4FC, and L-FMAU.

Although further studies are needed to address the cytotoxicity of thesedrugs in humans, the doses of the compounds used in our study are far below the toxic doses reported by others. Using 2.2.15 cells, no apparent cytotoxicity was noted at concentrations greater than $1,000,150$, and $30 \mu \mathrm{M}$ for lamivudine, ad efovir, and entecavir, respectively $(34,45,46)$. For L-D 4FC, the concentration required to inhibit $50 \%$ of $\mathrm{HepG} 2$ growth was estimated to be $20 \mu \mathrm{M}$ (35). Unfortunately, L-D 4FC is cytotoxic in various cells and with prolonged treatment has been shown to increaselactic acid production in HepG2 (47). L-FMAU ( \pm )-FTC, and (-)FTC did not show any cytotoxicity up to $200 \mu \mathrm{M}$ in 2.2.15 cells (36-38). In addition, with the exception of entecavir, in vivo studies have shown that these compounds are not associated with overt toxicity at high doses (>100 mg/ $\mathrm{kg}$ ). In duck hepatitis B virus-infected ducklings, treatment with $15-30 \mathrm{mg} / \mathrm{kg}$ of adefovir or $40 \mathrm{mg} / \mathrm{kg}$ of L-FMAU produced no toxic side effects $(46,48)$. In the woodchuck model, $0.5-0.1 \mathrm{mg} / \mathrm{kg}$ of entecavir, $1-4 \mathrm{mg} / \mathrm{kg}$ of L-D 4FC, or $20-30 \mathrm{mg} / \mathrm{kg}$ of $(-)$-FTC inhibited replication of woodchuck hepatitis virus without associated toxicity (49-52).

As learned from thetreatment of $\mathrm{HIV}$, it is likely that combinations of HBV drugs should be used to maximize suppression of replication and consequently decrease the probability of the emergence of a drugresistant virus $(40,53,54)$. This approach would permit the use of lower doses of the antiviral agents and, therefore, reducethelikelihood of side effects. It al so seems advantageous to combine adefovir with lamivudine, entecavir, L-D 4FC, L-FM AU, or (-)-FTC in an effort to better suppress HBV replication and del ay the development of resistance. Although entecavir, L-D 4FC, and L-FM AU had the lowest EC ${ }_{50}$, a combination of these three drugs may be compromised, as they have a similar cross-resistance profile. Further studies are necessary to determine the potential synergistic interaction of compounds in combination therapy.

\section{Acknowledgments}

This study was supported by a Research Grant for Immunology, Allergy, and Organ Transplantation from the M inistry of Health and Welfare, Japan. S.K. Ono is a Research Fellow of the Japan Society for the Promotion of Science. R.F. Schinazi is supported in part by the Department of Veterans Affairs and N IH grant RO 1-Al-41980. Wethank Mitsuko Tsubouchi for technical assistance. N either this study nor the authors received grant support from the pharmaceutical companies whose products are examined.

1. World Health Organization warns of growing "crisis of suffering." http://www.who.ch/whr/1997/presse.htm.

2. Gordon, D., and Walsh, J.H. 1998. Hepatitis drugs win approval. Gastroenterology. 116:235-236.

3. Honkoop, P., de M an, R.A., Zondervan, P.E., and Schalm, S.W. 1997. Histological improvement in patients with chronic hepatitis B virus infection treated with lamivudine. Liver. 17:103-106.

4. Lai, C.L., et al. 1998. A one-year trial of lamivudine for chronic hepatitis B. Asia H epatitis Lamivudine Study Group. N. Engl. J. M ed. 339:61-68.

5. O mata, M. 1998. Treatment of chronic hepatitis B infection. N. Engl. J. Med. 339:114-115.

6. Lai, C.L. 1999. Antiviral therapy for hepatitis B and C in Asians. J. Gastroenterol. H epatol. 14(Suppl.):S19-S21.

7. Bartholomew, M.M., et al. 1997. H epatitis-B-virus resistance to lamivudinegiven for recurrent infection after orthotopic liver transplantation. Lancet. 349:20-22.

8. Ling, R., et al. 1996. Selection of mutations in the hepatitis B virus polymerase during therapy of transplant recipients with lamivudine. H epatology. 24:711-713.

9. Tipples, G.A., et al. 1996. M utation in HBV RNA-dependent DNA polymerase confers resistance to lamivudine in vivo. H epatology. 24:714-717.

10. Allen, M.I., et al. 1998. Identification and characterization of mutations in hepatitis B virus resistant to lamivudine. Lamivudine Clinical Investigation Group. H epatology. 27:1670-1677.

11. Chayama, K., et al. 1998. Emergence and takeover of YMDD motif mutant hepatitis $B$ virus during long-term lamivudine therapy and re takeover by wild type after cessation of therapy. Hepatology. 27:1711-1716.

12. Yeh, C.T., Chien, R.N ., Chu, C.M ., and Liaw, Y.F. 2000. Clearance of the original hepatitis $B$ virus YMDD-motif mutants with emergence of distinct lamivudineresistant mutants during prolonged lamivudine therapy. H epatology. 31:1318-1326.

13. Benhamou, Y., et al. 1999. Long-term incidence of hepatitis B virus resistanceto lamivudinein human immunodeficiency virus-infected patients. Hepatology. 30:1302-1306.

14. Bartholomeusz, A., Schinazi, R.F., and Locarnini, S.A. 1998. Significance of mutations in the hepatitis $B$ virus polymerase selected by nucleoside anal ogues and implications for controlling chronic disease. Viral H epatitisReviews. 4:167-187.

15. Lau, D.T.-Y., et al. 2000. Long-term lamivudinetherapy for chronic hepatitis B. Antivir. Ther. 5(Suppl. 1):43. (Abstr.)

16. Poch, O., Sauvaget, I., D elarue, M ., and Tordo, N . 1989. Identification of four conserved motifs among the RNA-dependent polymeraseencoding elements. EM BO J. 8:3867-3874.

17. Kamer, G., and Argos, P. 1984. Primary structural comparison of RNAdependent polymerases from plant, animal and bacterial viruses. N ucleic Acids Res. 12:7269-7282.

18. Ono-N ita, S.K., et al. 1999. YM DD motif in hepatitis B virus DN A polymerase influences on replication and lamivudine resistance: a study by in vitro full-length viral DNA transfection. H epatology. 29:939-945.

19. M elegari, M., Scaglioni, P.P., and Wands, J.R. 1998. Hepatitis B virus mutants associated with $3 \mathrm{TC}$ and famciclovir administration are replication defective. H epatology. 27:628-633.

20. Jacobo-M olina, A., et al. 1993. Crystal structure of human immunodeficiency virus type 1 reversetranscriptase complexed with double-stranded DNA at 3.0 A resolution shows bent DN A. Proc. N atl. A cad. Sci. USA. 90:6320-6324.

21. Seigneres, B., et al. 2000. Evolution of hepatitis B virus polymerasegene sequence during famciclovir therapy for chronic hepatitis B. J. Infect. Dis. 181:1221-1233.

22. Liaw, Y.F., Chien, R.N ., Yeh, C.T., Tsai, S.L., and Chu, C.M . 1999. Acute exacerbation and hepatitis $B$ virus clearance after emergence of YMDD motif mutation during lamivudine therapy. H epatology. 30:567-572.

23. Ben-Ari, Z., Pappo, O., Zemel, R., M or, E., and Tur-Kaspa, R. 1999. Association of lamivudine resistance in recurrent hepatitis $B$ after liver transplantation with advanced hepatic fibrosis. Transplantation. 68:232-236.

24. Bessesen, M., Ives, D., Condreay, L., Lawrence, S., and Sherman, K.E. 1999. Chronic active hepatitis B exacerbations in human immunodeficiency virus-infected patients following development of resistanceto or 
withdrawal of lamivudine. Clin. Infect. Dis. 28:1032-1035.

25. Ono-N ita, S.K., et al. 1999. Susceptibility of lamivudineresistant hepatitis B virus to other reverse transcriptase inhibitors. J. Clin. Invest. 103:1635-1640.

26. Merchant, Z., et al. 1997. BMS-200475, a novel carbocyclic 2'deoxyguanosine analog with potent and selective anti-hepatitis $B$ virus activity in vitro. Bioorg. M ed. Chem. Lett. 7:127-132.

27. N akabayashi, H., Taketa, K., M iyano, K., Yamane, T., and Sato, J. 1982 Growth of human hepatoma cells lines with differentiated functions in chemically defined medium. Cancer Res. 42:3858-3863.

28. Sells, M.A., Chen, M .L., and Acs, G. 1987. Production of hepatitis B virus particles in $\mathrm{H}$ ep $\mathrm{G} 2$ cells transfected with cloned hepatitis B virus D N A. Proc. Natl. Acad. Sci. USA. 84:1005-1009.

29. Togo, G., et al. 1996. A transforming growth factor beta typell receptor gene mutation common in sporadic cecum cancer with microsatellite instability. Cancer Res. 56:5620-5623.

30. Günther, S., et al. 1995. A novel method for efficient amplification of whole hepatitis $B$ virus genomes permits rapid functional analysis and reveals deletion mutants in immunosuppressed patients. J. Virol. 69:5437-5444.

31. Yokosuka, O., O mata, M.,Imazeki, F., Okuda, K., and Summers, J. 1985 Changes of hepatitis B virus DNA in liver and serum caused by recombinant leukocyte interferon treatment: analysis of intrahepatic replicative hepatitis B virus D N A. H epatology. 5:728-734.

32. Dienstag, J.L., et al. 1999. Lamivudine as initial treatment for chronic hepatitis B in the United States. N . Engl. J. M ed. 341:1256-1263.

33. Fu, L., and Cheng, Y.C. 1998. Role of additional mutations outside the YMDD motif of hepatitis $B$ virus polymerase in L(-)SddC (3TC) resistance. Biochem. Pharmacol. 55:1567-1572.

34. Innaimo, S.F., et al. 1997. Identification of BM S-200475 as a potent and selective inhibitor of hepatitis $B$ virus. Antimicrob. Agents Chemother. 41:1444-1448.

35. Zhu, Y.L., Dutschman, D.E., Liu, S.H., Bridges, E.G., and Cheng, Y.C. 1998. Anti-hepatitis B virus activity and metabolism of 2 ', $3^{\prime}$-dideoxy2',3'-didehydro-beta-L(-)-5-fluorocytidine. Antimicrob. Agents Chemother 42:1805-1810.

36. Balakrishna Pai, S., Liu, S.H., Zhu, Y.L., Chu, C.K., and Cheng, Y.C. 1996 Inhibition of hepatitis B virus by a novel L-nucleoside, 2'-fluoro-5methyl-beta-L-arabinofuranosyl uracil. Antimicrob. Agents Chemother 40:380-386.

37. Jansen, R.W., Johnson, L.C., and Averett, D.R. 1993. High-capacity in vitro assessment of anti-hepatitis $B$ virus compound selectivity by a virionspecific polymerase chain reaction assay. Antimicrob. A gents Chemother. 37:441-447.

38. Furman, P.A., et al. 1992. Theanti-hepatitis B virus activities, cytotoxicities, and anabolic profiles of the (-) and (+) enantiomers of cis-5-fluoro1-[2-(hydroxymethyl)-1,3-oxathiolan-5-yl]cytosine. Antimicrob. Agents Chemother. 36:2686-2692

39. Hirsch, M.S., et al. 1998. Antiretroviral drug resistancetesting in adults with HIV infection: implications for clinical management. Internation- al AIDS Society-USA Panel. JAM A. 279:1984-1991.

40. Condra, J.H. 1998. Resisting resistance: maximizing the durability of antiretroviral therapy. Ann. Intern. Med. 128:951-954.

41. Coffin, J.M. 1995. HIV population dynamics in vivo: implications for genetic variation, pathogenesis, and therapy. Science. 267:483-489.

42. Tsiang, M., Rooney, J.F., Toole, J.J., and Gibbs, C.S. 1999. Biphasic clearancekinetics of hepatitis $B$ virus from patients during adefovir dipivoxil therapy. H epatology. 29:1863-1869.

43. Havlir, D.V., and Richman, D.D. 1996. Viral dynamics of HIV: implications for drug devel opment and therapeutic strategies. Ann. Intern. M ed. 124:984-994.

44. Peters, M., et al. 2000. Adefovir dipivoxil treatment of hepatitis B virus disease in patients failing lamivudine therapy. Antivir. Ther. 5(Suppl. 1):45.

45. Kruining, J., H eijtink, R.A., and Schalm, S.W. 1995. Antiviral agents in hepatitis B virus transfected cell lines: inhibitory and cytotoxic effect related to time of treatment. J. H epatol. 22:263-267.

46. Heijtink, R.A., et al. 1993. Inhibitory effect of 9-(2-phosphonylmethoxyethyl)-adenine (PMEA) on human and duck hepatitis B virus infection. Antiviral Res. 21:141-153.

47. Shi, ., et al. 1999. Synthesis and biological evaluation of 2',3'-didehydro2',3'-dideoxy-5-fluorocytidine (D 4FC) analogues: discovery of carbocyclic nucleoside triphosphates with potent inhibitory activity against HIV-1 reverse transcriptase. J. M ed. Chem. 42:859-867.

48. Aguesse-Germon, S., et al. 1998. Inhibitory effect of 2'-fluoro-5-methylbeta-L-arabinofuranosyl-uracil on duck hepatitis $B$ virus replication. Antimicrob. Agents Chemother. 42:369-376.

49. Genovesi, E.V., et al. 1998. Efficacy of the carbocyclic 2'-deoxyguanosine nucleoside BM S-200475 in the woodchuck model of hepatitis B virus infection [erratum 1999, 43:726]. Antimicrob. Agents Chemother. 42:3209-3217.

50. Le Guerhier, F., et al. 1999. 2',3'-dideoxy-2',3'-didehydro-b-L-5-fluorocytidine (b-L-FD 4C) exhibits a more potent antiviral effect than lamivudine in chronically WHV infected woodchucks. H epatology. 30:344A. (Abstr.)

51. Cullen, J.M., et al. 1997. In vivo antiviral activity and pharmacokinetics of (-)-cis-5-fluoro-1-[2-(hydroxymethyl)-1,3-oxathiolan-5-yl]cytosine in woodchuck hepatitis virus-infected woodchucks. Antimicrob. Agents Chemother. 41:2076-2082.

52. Korba, B.E., Schinazi, R.F., Cote, P., Tennant, B.C., and Gerin, J.L. 2000. Effect of oral administration of emtricitabine on woodchuck hepatitis virus replication in chronically infected woodchucks. Antimicrob. Agents Chemother. 44:1757-1760.

53. Balzarini, J. 1999. Suppression of resistanceto drugs targeted to human immunodeficiency virus reverse transcriptase by combination therapy. Biochem. Pharmacol. 58:1-27.

54. Schinazi, R.F. 1991. Combined therapeutic modalities for viral infections: rationale and clinical potential. In Synergism and antagonism in chemotherapy. T.-C. Chou and D.C. Rideout, editors. Academic Press. Orlando, Florida, USA. 110-181 